\begin{tabular}{|c|c|}
\hline $\begin{array}{l}\text { ціональний університет імені Василя Стефаника" } \\
\text { (Івано-Франківськ, Україна) }\end{array}$ & $\begin{array}{l}\text { yl Stefanyk Precarpathian National University (Ivano- } \\
\text { Frankivsk, Ukraine) }\end{array}$ \\
\hline \multicolumn{2}{|l|}{$\begin{array}{l}\text { e-mail: edlap55@gmail.com } \\
\text { http://orcid.org/0000-0002-7717-2236 }\end{array}$} \\
\hline $\begin{array}{l}\text { Яців Ярослав Миколайович - кандидат педаго- } \\
\text { гічних наук, професор, декан факультету фізичного } \\
\text { виховання і спорту, ДВНЗ “Прикарпатський націо- } \\
\text { нальний університет імені Василя Стефаника” (Іва- } \\
\text { но-Франківськ, Україна) }\end{array}$ & $\begin{array}{l}\text { Yatsiv Yaroslav Mykolaiovych - Candidate of Science } \\
\text { (Education), Professor, Dean of the Faculty of Physical } \\
\text { Education and Sports, Vasyl Stefanyk Precarpathian } \\
\text { National University (Ivano-Frankivsk, Ukraine) }\end{array}$ \\
\hline \multicolumn{2}{|l|}{$\begin{array}{l}\text { e-mail: yatsiv64@ gmail.com } \\
\text { http://orcid.org/0000-0003-2474-0401 }\end{array}$} \\
\hline $\begin{array}{l}\text { Лісовський Богдан Петрович - кандидат біоло- } \\
\text { гічних наук, доцент, ДВНЗ “Прикарпатський на- } \\
\text { ціональний університет імені Василя Стефаника" } \\
\text { (Івано-Франківськ, Україна) }\end{array}$ & $\begin{array}{l}\text { Lisovskyi Bohdan Petrovych - Candidate of Science } \\
\text { (Biology), Associate Professor (Ph. D.), Vasyl Stefa- } \\
\text { nyk Precarpathian National University (Ivano- } \\
\text { Frankivsk, Ukraine) }\end{array}$ \\
\hline $\begin{array}{l}\text { e-mail: lisovsky.bogdan@ gmail.com } \\
\text { https://orcid.org/0000-0003-0474-9572 }\end{array}$ & \\
\hline
\end{tabular}

УДК 378.147.7.96-051[005.342

doi: 10.15330/fcult.33.56-62

Андрій Молдован

\title{
ДО ПИТАННЯ ПРО ПІДГОТОВКУ МАЙБУТНІХ ФАХІВЦІВ 3 ФІЗИЧНОГО ВИХОВАННЯ І СПОРТУ ДО ПІДПРИЕМНИЦЬКОЇ ДІЯЛЬНОСТІ В РЕАЛІЯХ ПОСТІНДУСТРІАЛЬНОГО СУСПІЛЬСТВА
}

Особливою рисою постіндустріального суспільства є важливість інформації для економічного $і$ соціального прогресу. Саме це дозволяе говорити про інтелектуалізацію економіки, про економіку, що базується на знаннях. У зв'язку з иим уряди, підприємиі, громадськість більшості краӥн світу все більше усвідомлюють, як важливо мати якісну інформачію з широкого кола питань. Це дозволяє забезпечити раціональне прогнозування та керування економічними і соціальними процесами для прийняття науково обгрунтованих рімень з різноманітних і складних проблем суспільного розвитку.

У статті розглянуто теоретичні основи підприємництва, тенденції та проблеми розвитку фiзичної культури та спорту, передумови розвитку підприємницької діяльності у сфері фізичної культури та спорту. Проаналізовано функиії підприємництва у галузі фізичної культури і спорту. Охарактеризовано відмінні риси різних організаційно-правових форм спортивних комерційних організацій. На цій основі обтрунтовано значення сфери фізичної культури і спорту як соціальної системи, розкрито організаційну структуру управління вітчизняним фізкультурно-спортивним рухом, охарактеризовано особливості функиіонування иієї системи на сучасному етапі.

Професійна підготовка майбутніх фахівців у сфері фізичної культури $і$ спорту до підприємницької діяльності була зумовлена швидкими змінами в сочіально-економічному, політичному житті країни, викликами глобалізації, об'єктивними потребами підвищення якості зростанням рівня вимог до навчально-методичного, науково-методччного та інформачійного забезпечення професійної компетентності цих фахівців з урахуванням їхніх особистісно-професійних запитів і потреб, професійного досвіду.

Тому все актуальнішими стають проблеми підвищення якості підготовки майбутніх фахівців у сфері фізичної культури до підприємницької діяльності в реаліях сьогоднішнього постіндустріального суспільства.

Ключові слова: постіндустріального суспільства, підприємницька діяльність, фізична культура $і$ cnopm.

Objective: a Special feature of post-industrial society is the importance of information for economic and social progress. This is what allows us to talk about the intellectualization of the economy, the economy based on knowledge. In this regard, governments, entrepreneurs, the public in most countries of the world are increasingly aware of the importance of having quality information on a wide range of issues. It allows to provide rational forecasting and management of economic and social processes for making scientifically proved decisions from various and difficult problems of social development. 
The article deals with the theoretical foundations of entrepreneurship, trends and problems of physical culture and sports, the prerequisites for the development of entrepreneurial activity in the field of physical culture and sports. The definition of entrepreneurial activity in the sphere of physical culture and sports is proposed. The functions of entrepreneurship in the sphere of physical culture and sports are analyzed. The distinctive features of various organizational and legal forms of commercial sports organizations are characterized. On this basis, the importance of the sphere of physical culture and sports as a social system is justified, the organizational structure of the management of the domestic sports movement is revealed. the features of the functioning of this system at the present stage are characterized.

Professional training of future specialists in the field of physical culture and sports for entrepreneurial activity was due to rapid changes in the socio-economic, political life of the country, the challenges of globalization, the objective needs of improving the quality of the growing level of requirements for educational, scientific, methodological and information support of professional competence of these specialists, taking into account their personal and professional needs and professional experience. Therefore, the problems of improving the quality of training of future specialists in the field of physical culture for entrepreneurial activity in the realities of today's post-industrial society are becoming more and more urgent.

Key words: post-industrial society, entrepreneurial activity, physical culture and sport.

\section{Постановка проблеми й аналіз результатів останній досліджень.}

Аналіз літературних джерел показав, що модернізація системи освіти на сучасному етапі розвитку суспільства висуває нові вимоги до професійної підготовки фахівців фізичної культури. Їх зміст полягає у застосуванні педагогами нових технологій, формуванні нових орієнтирів щодо вирішення проблем виховання.

Підготовка готовності майбутніх фахівців фізичної культури і спорту у вищих навчальних закладах до професійної діяльності набуває сьогодні винятково важливого значення. Адже вона має забезпечуватися не тільки навчально-виховним процесом майбутніх фахівців, спеціальними знаннями, вміннями та навичками, а й розвитком у них компетенційних якостей особистості, його інтелектуального потенціалу, внутрішніх можливостей, інтересів, здібностей, мотиваційних і ціннісних настанов.

Фізична культура і спорт як соціальний інститут і специфічний вид професійної діяльності активно впливає на розвиток здорового суспільства і зазнає нині глибокі кількісні, структурні і якісні перетворення. Вони зумовлені, насамперед, новими соціально-економічними. демографічними і політичними умовами. Перехід до ринкових відносин породив безліч проблем в цій особливій сфері соціальної діяльності.

Ринкові відносини докорінно змінили значення і вплив соціальних інститутів на різних рівнях. Комерціалізація інфраструктури фізичної культури та спорту має не тільки позитивні. але і негативні наслідки. Зараз йдеться про пошук нових ефективних форм і видів комерційної діяльності в системі фізичної культури і спорту. щоб забезпечити задоволення потреб населення.

Процес формування якісно нової моделі господарської діяльності з організації та надання фізкультурно-оздоровчих і спортивних послуг відбувається одночасно 3 пошуком можливих способів руху до неї. Колишня практика їх організації переважно шляхом державного фінансування. не відповідає новим соціально-економічним умовам. а підприємницька діяльність у цій галузі ще перебуває на початковій стадії свого формування і розвитку. що вимагає проведення наукових досліджень. які ставлять своєю метою вдосконалення теоретичної бази для організації ефективної системи управління в сфері спорту і фізичної культури.

Мета дослідження. Здійснити комплексний науковий аналіз стану підготовки майбутніх фахівців в галузі фізичної культури і спорту до підприємницької діяльності в контексті подальшої розробки та впровадження цілісної системи професійної підготовки майбутніх фахівців з підприємницької діяльності у реаліях постіндустріального суспільства. 
Методи й організація дослідження. Пошукове дослідження стану підготовки майбутніх фахівців фізичної культури до підприємницької діяльності проводилося 3 метою вивчення проблеми в іiі теоретичному та практичному аспектах; пошуку шляхів вирішення висунутих проблем. Ми виокремили такі завдання дослідження стану підготовки майбутніх фахівців фізичної культури до підприємницької діяльності студентами факультету фізичної культури та здоров'я людини:

- вивчити розуміння студентами необхідності використання підприємницьку діяльність в професійній підготовці фахівця галузі фізичної культури і спорту;

- з'ясувати причини відсутності знань з підприємницької діяльності;

- виявити труднощі, які виникають у студентів у процесі навчання;

- визначити задоволеність студентів рівнем освіти;

- визначити відсоток студентів, які зацікавлені у вивченні підприємницької діяльності;

- вивчити розуміння студентами ролі підприємницької діяльності в їх майбутній кваліфікації;

- визначити зацікавленість студентів до формування умінь з організації підприємницької діяльності.

Результати і дискусія. Для вирішення поставленого завдання дослідження нами був визначений контингент студентів факультету фізичної культури та здоров'я людини Чернівецького національного університету імені Юрія Федьковича. 3 метою визначення динаміки ставлення студентів до підприємницької діяльності в процесі навчання, ми провели опитування студентів другого, третього, четвертого та п'ятого курсу факультету фізичної культури та здоров'я людини спеціальності “Фізична культура i спорт".

За результатами опитування щодо розуміння студентами ролі підприємницької діяльності в професійній підготовці фахівців галузі фізичної культури і спорту лише $18 \%$ студентів другого курсу вважають підприємницьку діяльність важливою складовою професійної підготовки сучасного фахівця галузі фізичної культури і спорту; 35\% більш схильні до важливості ролі підприємницької діяльності в професійній підготовці майбутнього фахівця галузі фізичної культури і спорту; 32\% ще не визначили свого ставлення; 15\% студентів не вважають підприємницьку діяльність важливою складовою професіоналізму сучасного фахівця сфери фізичного виховання (рис. 1).

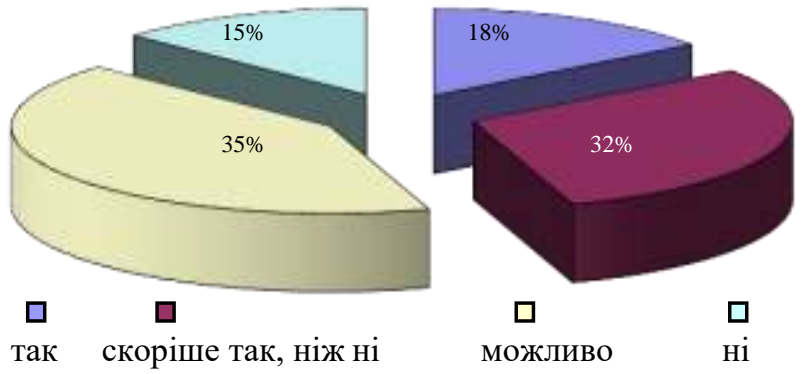

Puc. 1. Визначення студентами 1 курсу ролі підприємницької діяльності у професійній підготовці фахівців фізичної культури і спорту

Вивчення ступеня розуміння студентами другого курсу факультету фізичної культури і здоров'я людини ролі підприємницької діяльності в професійній підготовці фахівців галузі фізичної культури і спорту з'ясувало, що 24\% студентів вважають підприємницьку діяльність важливою складовою професіоналізму сучасного фахівця галузі фізичної культури і спорту. Більш схильні до прийняття необхідності підприємницької 
діяльності у професійному становленні майбутнього фахівця галузі фізичної культури і спорту $36 \%$ респондентів; 29\% ще не визначили свого ставлення; $11 \%$ не вважають підприємницьку діяльність студентів важливою складовою професіоналізму сучасного фахівця галузі фізичної культури (рис. 2).

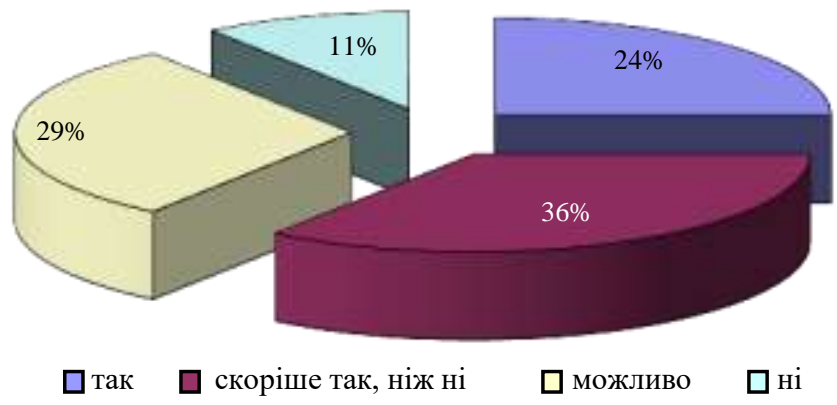

Рuc. 2. Визначення студентами 2 курсу ролі підприємницької діяльності у професійній підготовці фахівців фізичної культури і спорту

Серед студентів третього курсу факультету фізичної культури та здоров'я людини значну роль підприємницької діяльності у професійному становленні фахівця галузі фізичної культури і спорт визнали 33\% респондентів, 37\% опитуваних більш схильні до прийняття важливості ролі науково-дослідницької діяльності в професійному становленні майбутнього фахівця в галузі фізичної культури і спорт; $21 \%$ ще не визначили свого ставлення; 9\% не вважають підприємницьку діяльність студентів важливою складовою професійної підготовки сучасного фахівця фізичної культури і спорту (рис. 3).



Рuc. 3. Визначення студентами 3 курсу ролі підприємницької діяльності у професійній підготовці фахівців фізичної культури і спорту

Вивчаючи розуміння студентами п’ятого курсу факультету фізичної культури та здоров'я людини ролі підприємницької діяльності у професійному становленні фахівця галузі фізичної культури і спорту, ми з'ясували, що вже 65\% студентів вважають підприємницьку діяльність важливою складовою професіоналізму сучасного фахівця фізичної культури і спорту; 25\% більш схильні до важливості підприємницької діяльності в професіоналізмі майбутнього фахівця галузі фізичної культури і спорту; 7\% ще не визначили свого ставлення та лише $3 \%$ респондентів не вважають підприємницьку діяльність студентів важливою складовою підготовки сучасного фахівця в галузі фізичної культури і спорту (рис. 4).

Така відмінність показників пояснюється тим, що студенти першого та другого курсу на протязі року не вивчали жодну дисципліну зв'язану з підприємницькою діяльністю, студенти третього та п'ятого курсу вивчали 'Економіку фізичної культури i 
спорту”, “Маркетинг фізичної культури і спорту”, “Менеджмент спортивних організацій” вони вже мають початкові знання з цього виду діяльності.

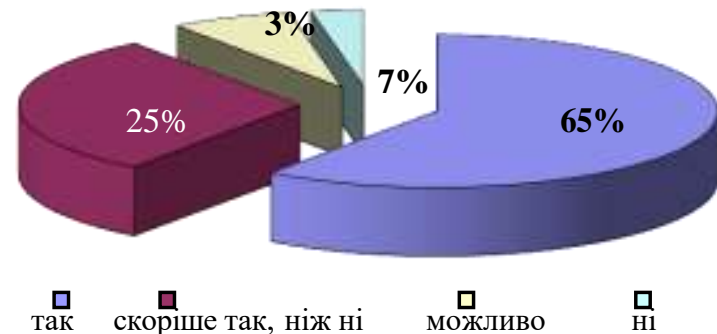

Puc. 4. Визначення студентами 5 курсу ролі підприємницької діяльності у професійній підготовці фахівців фізичної культури спорту

Результати визначення динаміки ставлення студентів факультету фізичної культури та здоров'я людини до визначення важливості ролі підприємницької діяльності у професійній підготовці фахівців в галузі фізичної культури і спорту надані на рис. 5.

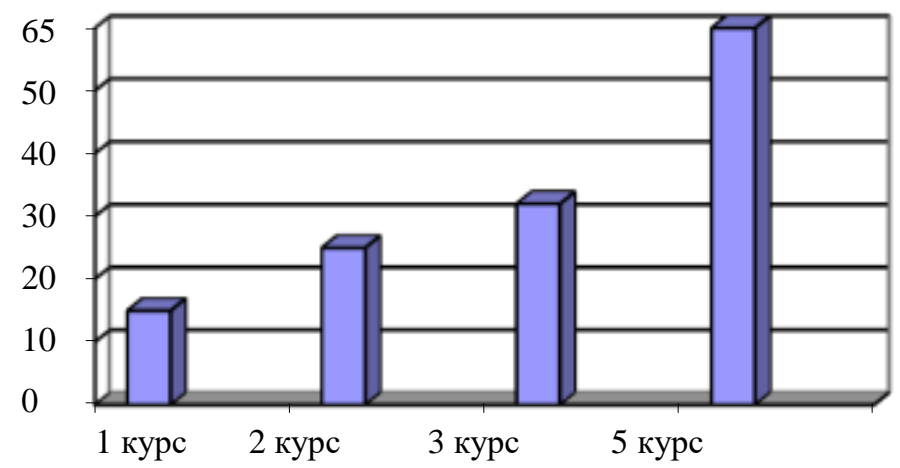

Рис. 5. Динаміка визнання студентами важливості ролі підприємницької діяльності у професійній підготовці фахівців галузі фізичної культури і спорту

Отже, професійна підготовка майбутніх фахівців розглядається як цілісна система, яка будується на основі органічного об'єднання загального та індивідуального розвитку особистості. Результати дослідження дозволили визначити недостатню зацікавленість студентів факультету фізичної культури і здоров'я людини до підприємницької діяльності, причиною якої є недостатні знання щодо організації підприємницької діяльності та недостатній рівень знань з даного виду діяльності; необхідність застосування підприємницькій діяльності у професійній підготовці фахівців сфери фізичної культури і спорту; необхідність активного залучення студентів до вивчення підприємницької діяльності.

Не зважаючи на наявність значної кількості досліджень в даній галузі багато питань, зокрема, стосовно факторів, які визначають особливості підприємницької діяльності в галузі залишається недостатньо дослідженою.

Варто зазначити, що дослідження підприємництва у сфері спорту носять фрагментарний характер, вивчаються окремі питання, пов'язані з розвитком професійного спорту та фітнес-індустрії; існує суперечливість думок щодо визначення підприємницької діяльності в галузі фізичної культури і спорту, її основних функцій, залишаються недостатньо дослідженими особливості та проблеми підприємництва у сфері фізичної культури і спорту в умовах ринкових перетворень. 
Висновки. Здійснений комплексний науковий аналіз стану підготовки студентів показав, що підготовку майбутніх спеціалістів підприємницької діяльності доцільно здійснювати в системі професійної підготовки майбутніх фахівців в галузі фізичної культури і спорту. Так як вона $є$ складовою професійної підготовки майбутніх фахівців фізичної культури і спорту та має свою специфіку, і особливості. Визначені особливості полягають у тому, що такий фахівець має володіти професійними вміннями та навичками, притаманними тренеру в підприємницькій діяльності.

По завершенню нашого дослідження ми дійшли висновку, що підприємницька діяльність - це ефективний засіб господарювання в умовах ринкової економіки. Розвиток підприємницької діяльності у сфері фізичної культури і спорту забезпечує високу ефективність іï функціонування. Ефективне підприємництво у сфері фізичної культури та спорту можливе лише за наявності певної ситуації - підприємницького середовища, тобто ринкової системи відносин, а також свободи підприємця, яка дозволяє приймати найбільш ефективні рішення. Сприятливе підприємницьке середовище, включає в себе високий ступінь економічної свободи, наявність певних спортивних підприємств, домінування у сфері діяльності фізкультурно-спортивних організацій та підприємств економічних стосунків ринкового типу, можливість використання необхідних ресурсів фінансових, матеріальних, людських, наявність відповідного законодавства та оподаткування. Тому питання підприємництва у сфері спорту мають перебувати у фокусі уваги як дослідників, так і фахівців у сфері фізичної культури і спорту.

1. Гадайчук ДЛ. Результати досліджень 3 питань використання фінансових ресурсів організаційноуправлінськими структурами у спорті вищих досягнень. Педагогіка, психологія та медико-біологічні проблеми фізичного виховання і спорту. 2004;13:29-39.

2. Галкин ВВ. Економика спорта и спортивний бизнесс. Москва: Кнорус; 2006. 291 с.

3. Галкин ВВ. Економика спорта и спортивний бизнесс. Москва: КНОРУС, 2009. 320 с.

4. Друкер П. Еффективное управление. Москва: АСТ “Астрель”; 2004. 284 с.

5. Куделко ВЄ. Організація і технологія управління фізичною культурою і спортом в системі районного територіально-адміністративного утворення [автореферат]. Харків: ХДАФК; 2005. 22 с.

6. Кузьменко ОО. Реалізація державної програми у сфері фізичної культури і спорту. Науковий вісник молодих вчених. 2010; 1(1): 225-229.

7. Мічуда ЮП. Сфера фізичної культури і спорту в умовах ринку: закономірності функціонування та розвитку. Київ: Олімпійська л-ра, 2007. 215 с.

8. Мічуда ЮП. Професійний спорт як різновидність підприємницької діяльності. Теорія і методика фізичного виховання і спорту. 2005; 1:30-35.

9. Мічуда Ю. Проблеми розвитку підприємництва у сфері спорту для всіх. Теорія і методика фізичного виховання і спорту. 2007; 1: 82-86.

10. Павелко А. Спорт як специфічний об'єкт державної політики (на прикладі футболу). Актуальні проблеми державного управління. 2007; 1(27): 76-82.

11. Площинська А. Розвиток державної політики в галузі фізичної культури та спорту в сучасній Україні. Молода спортивна наука України. 2008; 12(2): 158-162.

12. Сериков ГН, Сериков СГ. Управление физкультурно-спортивной деятельностью. Челябинск : УралГУФК; 2011. 151 с.

\section{References}

1. Hadaychuk DL. Results of research on the use of financial resources by organizational and managerial structures in sport of higher achievements. Pedahohika, psykholohiya ta medyko-biolohichni problemy fizychnoho vykhovannya i sportu. 2004; 13: 29-39.

2. Halkyn VV. The economy of sports and sports business. Moskva: Knorus; 2006. $291 \mathrm{~s}$.

3. Halkyn VV. The economy of sports and sports business. Moskva: KNORUS, 2009. $320 \mathrm{~s}$.

4. Druker P. Effective management. Moskva: AST “Astrel”"; 2004. 284 s.

5. Kudelko VYE. Organization and technology of management of physical culture and sports in the system of regional territorial-administrative formation [avtoreferat]. Kharkiv: KHDAFK; 2005. $22 \mathrm{~s}$.

6. Kuz'menko OO. Realization of the state program in the field of physical culture and sports. Naukovyy visnyk molodykh vchenykh. 2010; 1(1): 225-229.

7. Michuda YUP. The field of physical culture and sports in the market conditions: regularities of functioning and development. Kyyiv: Olimpiys'ka 1-ra, 2007. $215 \mathrm{~s}$. 
8. Michuda YUP. Professional sport as a kind of entrepreneurial activity. Teoriya i metodyka fizychnoho vykhovannya i sportu. 2005; 1: 30-35.

9. Michuda YU. Problems of entrepreneurship development in the field of sport for all. Teoriya i metodyka fizychnoho vykhovannya i sportu. 2007; 1: 82-86.

10. Pavelko A. Sport as a specific object of state policy (for example, football). Aktual'ni problemy derzhavnoho upravlinnya. 2007; 1(27): 76-82.

11. Ploshchyns'ka A. Development of state policy in the field of physical culture and sports in modern Ukraine. Moloda sportyvna nauka Ukrayiny. 2008;12(2): 158-162.

12. Serykov HN, Serykov SH. Management of sports and sports activities. Chelyabynsk: UralHUFK; 2011. 151 s.

\title{
Цитування на цю статтю:
}

Молдован АВ. До питання про підготовку майбутніх фахівців з фізичного виховання і спорту до підприємницької діяльності в реаліях постіндустріального суспільства. Вісник Прикарпатського університету. Серія: Фізична культура. 2019 Берез 26; 33: 56-62

\begin{tabular}{|c|c|}
\hline Відомості про автора: & Information about the author: \\
\hline $\begin{array}{l}\text { Молдован Андрій Дмитрович - асистент, Чер- } \\
\text { нівецький національний університет імені Юрія } \\
\text { Федьковича (Чернівці, Україна) }\end{array}$ & $\begin{array}{l}\text { Moldovan Andrii Dmytrovych }- \text { Teaching Fellow, } \\
\text { Yuriy Fedkovych Chernivtsi National University } \\
\text { (Chernivtsi, Ukraina) }\end{array}$ \\
\hline $\begin{array}{l}\text { e-mail: moldovanandriy85@ gmail.com } \\
\text { https://orcid.org/0000-0003-2992-8868 }\end{array}$ & \\
\hline
\end{tabular}

\author{
УДК 796.819.015.5 \\ doi: 10.15330/fcult.33.62-66
}

Ігор Наконечний

\section{ВЗАСМОЗВ'ЯЗОК СПЕЦІАЛЬНОЇ ФІЗИЧНОЇ ТА ТЕХНІКО-ТАКТИЧНОЇ ПІДГОТОВКИ ВИСОКОКВАЛІФІКОВАНИХ СПОРТСМЕНІВ З ПАНКРАТІОНУ}

\begin{abstract}
Мета. Теоретично обтрунтувати та розробити програму спеціальної фізичної та технікотактичної підготовки висококваліфікованих спортсменів з панкратіону та перевірити ї̈ ефективність. Методи. Для розв'язання поставлених завдань було використано такі методи: аналіз і узагальнення даних науково-методичної літератури, тестування, педагогічний експеримент, методи математичної статистики, аналіз відео матеріалів змагальної діяльності спортсменів. У дослідженні взяли участь 20 спортсменів, які входять у збірну команду Украӥни з панкратіону, віком 17-31 рік. Педагогічний експеримент проводився на базі спортивного клубу “Голден Панкратіон”. Програма спеціальної фізичної та технікотактичної підготовки висококваліфікованих спортсменів експериментальної групи передбачала виконання наступних тренувальних завдань: вправи із спеціальними міні-обтяженнями протягом 2 хвилин та подальшими вириваннями суперника (прохід в ноги); виконання різноманітних кидків із спеціальними манекенами для боротьби; різноманітні удари ногами в різні рівні тримаючись за сітку протягом хвилини; згинання й розгинання рук в упорі лежачи з оплесками в долоні (перед грудьми, за головою, за спиною) протягом 30 c; удари руками (“бій з тінню”) з подальшим виконанням больових прийомів в партері; швидкісна робота з горизонтальними канатами протягом хвилини; вправи із двома спеціальними амортизаційними гумами (входи в ноги та удари); виконання спеціалізованих завдань зі зміною положень в партері з ударами (5 хвилин); ситуаційні техніко-тактичні завдання в партері з силовою роботою (3хв). Результат. В результаті проведеного педагогічного експерименту із застосуванням розробленої програми та порівняльного аналізу показників контрольної й експериментальної груп виявлені вірогідні зміни показників спеціальної фізичної підготовки (вибухові удари ногами по мішку та по спеціальним знаряддям за 30 c, удари руками по боксерському мішку на швидкість за 20 с, стрибки зі скакалкою за одну хвилину, удари по мішку в партері та зі стійки за одну хвилину, удари руками, ногами по мішку за одну хвилину). Щодо тактико-технічної підготовки, то виявлено наступне: 39,7\% висококваліфікованих спортсменів віддають перевагу змішаному стилю ведення поєдинку (удари, кидки, боротьба в партері); 16,3\% використовують стиль боротьби "Ударнік" (характерні виграні поєдинки ударною технікою); 16\% здійснюють поєдинок за стилем “Кидки”; 28\% спортсменів застосовують стиль “Партер”. Висновок. Отже, застосування в тренувальному процесі кваліфікованих спортсменів з панкратіону розробленої програми дозволяє оптимізувати рівень спеціальної фізичної й техніко-тактичної підготовки.
\end{abstract}

